\title{
Mathematical Interactive Multimedia To Improve Mathematical Reasoning Ability Of Senior High School Students
}

\author{
Nanang Priatna \\ Department of Mathematics Education, FPMIPA, \\ Indonesia University of Education \\ nanang_priatna@yahoo.com
}

\begin{abstract}
This study aims to determine the difference in the increase in mathematical reasoning ability between students who learn using mathematical interactive multimedia and students who learn using conventional learning, both in overall ability and by categories of early mathematical ability (high, medium, and low). This study is a quasi-experimental research with the experimental group learns through mathematical interactive multimedia and the control group learns through conventional learning. This study was conducted in one of Public Senior High Schools in Bandung with the subject sample consisted of two classes. Data was collected using an instrument in the form of mathematical reasoning ability test. Data analysis was performed on the average normalized gain between the two groups of samples by using t-test and two-way ANOVA. Early mathematical ability of students of both the experimental class and control class is divided into three groups, namely high, medium, and low. The results showed that the enhancement of mathematical reasoning ability of experimental group is better than the control group. Considering from early mathematical ability, there were significant differences in the increase of mathematical reasoning ability among the high, medium, and low ability students. There is an interaction between the learning method (using interactive multimedia and conventional) and the initial mathematical ability (high, medium, and low) in improving students' mathematical reasoning ability.
\end{abstract}

Keywords-Mathematics multimedia interactive; mathematical reasoning ability

\section{INTRODUCTION}

Mathematics should be offered to all learners from primary schools to equip learners with the ability to think logically, analytically, systematically, critically, innovatively, and creatively, as well as to develop the ability to cooperate. The competencies are required so that learners can have the ability to acquire, manage, and use information to live better on the always changing and highly competitive circumstances. Math skills are part of the life skills students need to have, especially in terms of reasoning, communication, and solutions to problems encountered in everyday life (Permendikbud/ Regulation of the Minister of Education and Culture No. 59 of 2014). Ruseffendi [17] confirms that the results of mathematical education are that students are creative, critical, capable to do scientific thinking, honest, thrift, disciplined, humane, have a sense of justice, and responsible for the welfare of the nation and the people.

Reasoning is a mental process or activity in developing thoughts of some facts or principles and outcome of mental processes in the form of knowledge or conclusions [16]. Therefore, reasoning becomes an essential and fundamental ability in mathematics learning and students should build this solidly, because reasoning helps students to think rationally.

The development of computers has become such an attraction in learning, especially the use of multimedia. Multimedia are media presentations using text, audio, and visual as well. Hofster [19] states that multimedia is the use of computers to create and combine text, graphics, audio, moving images (video and animation) by combining links and tools that allow users to navigate, interact, create, and communicate. Of some advantages in the use of interactive multimedia in learning, it could be an alternative for mathematics learning model to improve mathematical reasoning abilities in the classroom.

The research problems are formulated as follows:

1. Is the increase in mathematical reasoning skills among students who learn math through interactive multimedia better than students who learn math through conventional learning?

2. Is the increase in mathematical reasoning skills among students who learn math through interactive multimedia better than students who learn math through conventional learning by categories of high, medium, and low?

3. Is there any interaction between the learning (using mathematical interactive multimedia and conventional learning) and the initial mathematical ability (high, medium, and low) in improving students' mathematical reasoning ability?

\section{A. Learning Using Mathematical interactive multimedia}

The use of computer software for learning activity is unlimited [4] and the potential of computer technology as a medium of learning mathematics is so large [5]. Computers generate lots of real contribution to the advancement of 
education, especially math learning. Computers can be used to overcome individual differences of students and teaching concepts, to carry out calculations, and to stimulate student learning [6]. Students can set the pace of learning tailored to the level of ability. It is ideal for students who are difficult to follow the teaching of mathematics, especially students who are classified as slow learners. For students whose capacity is high (fast learners), they can be given enrichment so that they will feel more challenged to have the opportunity to explore the concept deeply.

Some studies [10] show that compared to conventional learning, interactive learning with computer media has several advantages. One of these advantages include the use of computers appropriately is able to enhance students' skills in math and students' control over the concepts learned, to create longer retention, and to form more positive attitudes of students toward mathematics.

Rusman, Kurniawan, \& Riyana[19]define computer-based multimedia as a technology that optimizes the computers' role as a means to display and manipulate text, graphics, and sound in an integrated view. Learning math using interactive multimedia learning can be defined as the use of technology to optimize the role of computers in learning to combine text, graphics, and sound in mathematical content so that it comes in an integral and attractive appearance that can create liveliness to those who use it.

The use of computers as an interactive learning medium is very suitable, in which computers can provide a good interaction with students who use it. This is in line with the opinion of Kelmanet al.[9] stating that "interaction is potential in computers".

\section{B. Mathematical Reasoning Ability}

Kusuma[11] reveals that reasoning is a way of thinking, which shows the relationship between two or more things based on specific nature and rules whose truth have been acknowledged by using certain steps until it reaches a conclusion. Additionally, Shaughnessy [23] states that reasoning is the process of drawing conclusions based on the evidence and assumptions given (justification, generalization, building toward proof). Lohman\&Lakin[12]confirm that reasoning is the process of drawing conclusions from the information. Baroody[1]presents three main types of reasoning, namely: intuitive reasoning, inductive reasoning, and deductive reasoning.

NCTM [14] says that in the implementation of mathematics in schools, teachers must pay attention to five mathematical abilities; those abilities are connections, reasoning, communications, problem solving, and representations. Therefore, mathematical reasoning became one of the goals to be achieved in learning mathematics in school. Reasoning is required to problem solving [14]; deductive and inductive reasoning appears when students solve a problem. Deductive process is associated with the logical reasoning of a statement or premise generalized to the general conclusion in the case, while inductive process is related to test the truth of a case, identify the relationship in the case, and generalize the relationship.
According to [7], reasoning to think mathematics is described as a high level of mathematical activity (doing Mathematics) which is an active, dynamic, and exploratory process. Dynamic here means looking for and find a pattern to understand mathematical structure and relationships, use the resources and tools to effectively formulate and solve problems, understand mathematical ideas, think and reason of mathematics, such as to generalize, use inference rules, make a conjecture, reason, communicate mathematical ideas, and to set or check the reasonableness of an answer or outcome. Thus, mathematics is a means to train critical, logical, rational, and systematic thinking.

Sumarmo[21] specifies that reasoning is classified into two types, namely inductive reasoning and deductive reasoning. Inductive reasoning is drawing general or specific conclusion based on the observed data, where the value of truth in inductive reasoning can be either true or false. Activities under inductive reasoning, among others are as follows. (a) Transductive, which is drawing conclusions from one case or specific case applied to the other specific cases. (b) Analogy, which is drawing conclusions based on similarity of data or processes. (c) Generalization, which is drawing general conclusions based on a number of the observed data. (d) Estimating answers, solutions or trends: interpolation and extrapolation. (e) Provide an explanation of the models, facts, nature, relationships, or the existing pattern. ( f) Using a pattern of relationships to analyze the situation and draw up a conjecture. Deductive reasoning is making inference based on agreed rules, where the value of truth in deductive reasoning is absolutely true or false, and not both. Activities under the deductive reasoning, among others are: a) carrying out calculations based on the rule or formula; b) drawing logical conclusion based on the rules of inference, checking the validity of the argument, proving, and making valid argument; and c) developing direct evidence, indirect evidence, and proving by mathematical induction.

Students need to have several mathematical reasoning skills. According to Mullis [22] these include the ability to find conjectures, analyses, evaluation, generalizations, connections, synthesis, non-routine problem solving, justifications or evidence, and mathematical communication skills. These abilities can arise when thinking about a problem or doing mathematical problem solving. By the time students are doing the activity, the components of the above reasoning does not appear in isolation but are interrelated to one another.

Ross [8]states that the indicators in mathematical reasoning are as follows: (a) Give reasons why an answer or approach to a problem is reasonable. (b) To analyze the claims and provides examples that can support or the opposite. (c) Using supporting data to explain why the means used and the answer are correct. (d) Create and evaluate general conclusions based on investigation and research. (e) Predicting or drawing conclusions or decisions of the appropriate information. (f) Considering the validity of arguments by using the inductive and deductive way of thinking.

Based on the above-mentioned explanation, reasoning in this study is inductive reasoning and deductive with the following indicators of (a) analogy, which is drawing 
conclusions based on similarity of data or processes; (b) generalization, which is drawing general conclusions based on a number of the observed data; and c) carrying out calculations based specific rules or formulas.

\section{RESEARCH METHOD}

This study used a quasi-experimental method, with a nonrandom pretest-posttest control design. This study used a $2 \times 3$ factorial design models, that refers to many factors of mathematics learning using interactive multimedia and conventional learning, as well as many factors of initial mathematical ability (high, medium, and low). It can be described as follows [18].

$$
\text { Experimental group }
$$

\begin{tabular}{lll}
$: O$ & $\mathrm{X}$ & $\mathrm{O}$ \\
\hdashline $\mathrm{O}$ & & $\mathrm{O}$
\end{tabular}

in which:

$$
\text { Control group }
$$

$$
\text { : } \mathrm{O}
$$

$\mathrm{X}=$ Learning through Mathematics Multimedia Learning (MIM)

\section{$\mathrm{O}=$ Pretest $/$ Postest}

The research subjects were two Science classes of Grade XI of a Public Senior High School in Bandung, in which one class was the experimental group and one class was the control group.

\section{RESULTS AND DISCUSSION}

Mathematical reasoning ability score is gained through pretest and posttest. The pretest and posttest scores were then computed to know normalized gain $(\mathrm{N}$-gain) of mathematical reasoning in the experimental class and control class. The following is a description of the pretest, posttest, and $\mathrm{N}$-gain the experimental class and control class.

TABLE I. DESCRIPTIVE STATISTICS OF STUDENTS' MATHEMATICAL REASONING ABILITY

\begin{tabular}{|c|c|c|c|c|c|c|c|}
\hline $\begin{array}{c}\text { Initial } \\
\text { Ability } \\
\text { Category }\end{array}$ & $\begin{array}{c}\text { Statis } \\
\text { tical } \\
\text { Data }\end{array}$ & \multicolumn{4}{|c|}{ MIM } & \multicolumn{3}{|c|}{ Conventional } \\
\cline { 3 - 8 } & & $\begin{array}{c}\text { Pre- } \\
\text { test }\end{array}$ & $\begin{array}{c}\text { Post- } \\
\text { test }\end{array}$ & $\begin{array}{c}\text { N- } \\
\text { gain }\end{array}$ & $\begin{array}{c}\text { Pre- } \\
\text { test }\end{array}$ & $\begin{array}{c}\text { Post- } \\
\text { test }\end{array}$ & $\begin{array}{c}\text { N- } \\
\text { gain }\end{array}$ \\
\hline \multirow{2}{*}{ High } & $\bar{x}$ & 18.40 & 80.68 & 0.84 & 17.00 & 63.50 & 0.56 \\
\cline { 2 - 8 } & SD & 4.45 & 3.90 & 0.13 & 4.97 & 4.22 & 0.03 \\
\hline \multirow{2}{*}{ Medium } & $\bar{x}$ & 23.57 & 83.38 & 0.79 & 20.68 & 57.63 & 0.47 \\
\cline { 2 - 8 } & SD & 5.43 & 6.10 & 0.07 & 5.72 & 5.22 & 0.04 \\
\hline \multirow{2}{*}{ Low } & $\bar{x}$ & 22.90 & 65.80 & 0.56 & 21.80 & 48.60 & 0.34 \\
\cline { 2 - 8 } & SD & 5.24 & 7.89 & 0.08 & 2.97 & 4.84 & 0.05 \\
\hline \multirow{2}{*}{ Total } & $\bar{x}$ & 22.15 & 80.68 & 0.74 & 20.03 & 56.82 & 0.46 \\
\cline { 2 - 8 } & SD & 5.19 & 5.94 & 0.09 & 5.18 & 7.25 & 0.09 \\
\hline \multicolumn{7}{|c|}{ Ideal Maximum Score $=100$} \\
\hline
\end{tabular}

The mean gain of mathematical reasoning ability when viewed from category the Initial Ability Category (IAC), it appears that the average IAC for high category of MIM class is 0.84 and 0.56 for conventional class. Average gain of MIM class is greater than the average gain of the conventional class, so learning through MIM brings good contribution in the development of mathematical reasoning ability for high IAC students. Average IAC for medium category of MIM class is
0.79 and 0.47 for conventional classes, in which the increase in the ability of mathematical reasoning for MIM class is in the high category while for conventional class is in the medium category; thus, MIM brings good contribution to the development of mathematical reasoning for the category of medium IAC. Average IAC for low category of MIM class is 0.56 and 0.34 for conventional classes, in which the increase in the ability of mathematical reasoning for MIM class and conventional class is in the medium category; thus, MIM does not really bring good contribution to the development of mathematical reasoning for the category of low IAC.

Viewed as a whole, MIM class gets an average gain of 0.74 and conventional class gets an average gain of 0.46 . The data shows that the increase in mathematical reasoning ability of MIM class is better than the conventional class.

TABLE II. TWO-WAY ANOVA THE INCREASE IN MATHEMATICAL REASONING ABILITY BASED ON IAC AND LEARNING METHOD

\begin{tabular}{|c|c|c|c|c|}
\hline Factor & df & $\begin{array}{c}\text { Mean } \\
\text { Square }\end{array}$ & F & Sig. \\
\hline IAC & 2 & 0.326 & 65.199 & 0.000 \\
\hline Learning & 1 & 1.311 & 261.965 & 0.000 \\
\hline $\begin{array}{c}\text { IAC* Learning } \\
\text { (interaction) }\end{array}$ & 2 & 0.017 & 3.468 & 0.036 \\
\hline
\end{tabular}

Based on test of interaction between learning using MIM and using conventional method and initial ability, we come to the conclusion that there is an interaction between learning (using multimedia interactive and conventional method) and initial mathematical ability (high, medium, and low) to increase the ability of mathematical reasoning.

This study uses two types of learning, that is learning mathematics using interactive multimedia (MIM) and conventional learning. The result show that MIM can develop mathematical reasoning ability. This is proven by higher $\mathrm{N}$ gain score of mathematical reasoning ability for MIM class, which is 0.74 , higher than the conventional learning of 0.46 . Based on the statistical test results, the increase in mathematical reasoning ability for MIM class is better than conventional class.

The results obtained from this study indicate that MIM plays role in developing mathematical reasoning ability. Reasoning ability is an important activity in mathematics [15]. In solving the problem, in addition to encouraging students to think, it can also help students to be more creative. As stated by Butts [2] that mathematics is essentially problem solving, therefore teachers should teach the art of solving problems through reasoning. Problems faced should make students motivated to solve them.

From the results obtained during the study, MIM can develop mathematical reasoning ability with a significant increase. Initial mathematical ability of students has a significant impact on the ability of mathematical reasoning. After learning, the average scores for MIM class on the posttest for the category of high, medium, and low is better than the conventional class. $\mathrm{N}$-gain group on mathematical 
reasoning ability of high, medium, and low category of MIM class is higher than conventional class.

The above description illustrates that initial mathematical ability contributes both in the acquisition of new knowledge for students. It can be concluded that initial mathematical ability of the students determines the learning outcome. If the initial ability of students is good, then learning gains will also be better.

The results show that the students' ability in mathematical reasoning for MIM class is relatively good, as the quality of student achievement is high with average posttest score of 80.68 while for the conventional class is 56.82 . Thus, it can be said that development of mathematical reasoning ability for MIM students is significantly better than students in conventional class.

Mathematical reasoning ability is one of the high-level thinking skills. Interactive multimedia program gives students in the experimental class the chance to explore their own ways of solving the existing problems, and show their answers with various alternative answers, because the use of computer software for learning activity is unlimited [4]. In addition, many students do the practice through student activity sheets (LKS). At this stage, they collect information, investigate the various issues presented not as a routine, and perform their own reasoning. This is in line with the opinion of Ruseffendi[17] that a way to capture creativity of thestudents is by equipping them with in-class activities, discussions, projects, and reasoning.

The use of mathematical interactive multimedia programs via computer as a medium of learning mathematics is not only able to improve students' mastery of concepts and attitudes as revealed by Kulik and Bagert-Drown [10], but the use of computers appropriately can improve students' mathematical reasoning ability. This is because in learning math using interactive multimedia give students practical exercises, tutorials, games, simulations, discovery and reasoning, as expressed by Glass [6]

The obstacle that causes less optimal improvement in the learning of mathematical reasoning using this interactive multimedia is that students are not familiar with learning through a problem and solve the problem. Thus, during the first meeting, the students had difficulty in reasoning process. However, the obstacle can be overcome in subsequent meetings by bringing students to understand the situation proposed, starting from what is known by the students. This is consistent with what is recommended by Rusman[20].

\section{CONCLUSION}

After going through a series of stages of the research, findings are produced, including the followings. First, it is the increase of mathematical reasoning ability among students who learn mathematics through interactive multimedia, which is better than students who learn through conventional learning. The increase in ability happens to all categories of high, medium, and low initial ability. There is an interaction between learning (using multimedia interactive and conventional method) and initial mathematical ability (high, medium, and low) to increase the ability of mathematical reasoning.

\section{References}

[1] Baroody, A.J. (1993). Problem Solving, Reasoning and Communicating, K-8 Helping Children Think Mathematically. New York. Macmillan Publishing Company.

[2] Butts, T. (1980). Posing Problem Properly. In S. Krulik \& R.E. Reys (Eds.). Problem Solving in School Mathematics. Washington D.C.: NCTM.

[3] Departemen Pendidikan dan Kebudayaan (2014). PeraturanMenteri Pendidikan dan KebudayaanNomor 59 Tahun 2014 tentang Kurikulum 2013 SekolahMenengah Aatas/Madrasah Aliyah. Jakarta: Depdikbud.

[4] Fey, J. Dan Heid, M.K. 1984. Imperatives and Possibilities For New Curricula in Secondary School Mathematics dalamComputers in Mathematics Education (Year Book). Hansen, V.P and Zweng, M.J (Editors). Reston, Virginia: NatioanalCouncill of Teachers of Mathematics, Inc.

[5] Fletcher,T.J. 1983. Microkomputers and Mathematics in Schools. United Kingdom: Department of Education and Scence.

[6] Glass, E.M. 1984. Computers: Challenge and Opportunity dalam Computers in Mathematics Education (Year Book). Hansen, V.P and Zweng, M.J (Editors). Reston, Virginia: Natioanal Councill of Teachers of Mathematics, Inc.

[7] Henningson, M, dan Stein, M. K. (1997). Mathematical Task and Student Cognition: Classroom-based Factor that Support and Inhibit High Level Mathematical Thinking and Reasoning. Journal for Research in Mathematic, 28, 524-549.

[8] Juandi, D. (2008). Pembuktian, Penalaran, dan Komunikasi Matematik. [Online].

Tersedia:http://file.upi.edu/Direktori/FPMIPA/Jur._Pend._Matematika/1 96401171992021-Dadang_Juandi/Penalaran_dan Pembuktian.pdf.

[9] Kelman, P. et al. 1983. Computers In Teaching Mathematics. Canada: Addison-Wesley Publishing Company, Inc.

[10] Kulik, J.A., Kulik, C.C., danBangert -Drowns, R.L. 1985. Effectivenest of Komputer-based Education in Elementary Shools [Online]. Tersedia: http://www.nwrel.org/scpd/sirs/5/cu10.html.

[11] Kusumah, S. Y. 1986. Logika Matematika Elementer. Bandung: Tarsito.

[12] Lohman, D.F \&Lakin, J.M. (2009). Reasoning and Intelligence. [Online].

Tersedia:http://faculty.education.uiowa.edu/dlohman/pdf/Reasoning\%20 and\%20Intell_Lohman\%20Lakin\%20102709.pdf.

[13] National Council of Teacher of Mathematics. 2000. Principle and Standards for School Mathematics. Reston, Va: NCTM.

[14] National Council of Teachers of Mathematics (1999). Developing Mathematical Reasoning in Grades K-12. Reston, VA: NCTM

[15] Priatna N., Martadipura B.A., Wibisono Y. (2013). Desaindan Pengembangan Multimedia Matematika Interaktif untuk Meningkatkan Kemampuan Penalaran, Komunikasi, dan Pemecahan Masalah Matematis Siswa SMA. Laporan Penelitian. Bandung: LPPM UPI.

[16] Priatna, N. (2012). Mengembangkan Kemampuan Penalaran dan Memecahkan Masalah melalui Strategi Daya Matematis Siswa di Sekolah. Pidato Pengukuhan Guru Besar UPI.

[17] Ruseffendi, E.T. (2006). Pengantar kepada Membantu Guru Mengembangkan Kompetensinya dalam Pengajaran Matematika untuk Meningkatkan CBSA. Bandung: Tarsito.

[18] Ruseffendi, E.T. 2010. Dasar-dasar Penelitian Pendidikan dan Bidang Non-Eksakta Lainnya. Bandung: Tarsito.

[19] [19]Rusman, Kurniawan, D. danRiyana, C. 2011. Pembelajaran Berbasis Teknologi Informasi dan Komunikasi: Mengembangkan Profesionalitas Guru. Jakarta: Rajawali Pers.

[20] Rusman. (2012). Model-model Pembelajaran: MengembangkanProfesionalisme Guru. Bandung: Tarsito Bandung.

[21] Sumarmo, U. (2010). Berfikirdan Disposisi Matematik: Apa, Mengapa, dan Bagaimana Dikembangkan pada PesertaDidik. FPMIPA UPI. [Online]. Tersedia:http://id.scribd.com/doc/76353753/Berfikir-DanDisposisi-Matematik-Utari.

[22] Suryadi, D. (2012). Membangun Budaya Baru dalam BerpikirMatematika. Bandung: Rizqi Press. 
[23] Yuliana, N. (2012). Pengaruh Pendekatan Differentiated Instruction terhadap Kemampuan Pemahaman, Penalaran, dan Kecemasan MatematisSiswa SMK. Tesis UPI Bandung: tidakditerbitkan. 